\title{
Factors Contributing to Mobile Phone Dependence
}

\author{
DB Jordaan \\ J Surujlal \\ North-West University, Faculty of Economic Sciences and Information Technology \\ PO Box 1174, Vanderbijlpark, 1900, Republic of South Africa \\ Email: Dawid.Jordaan@nwu.ac.za
}

\section{Doi:10.5901/mjss.2014.v5n21p371}

\section{Abstract}

Technology, especially mobile technology has dramatically invaded the lives of people in the past few years. Among the different mobile technologies is the mobile phone. The purpose of this study was to identify factors that contribute to mobile phone dependence. A quantitative research approach involving the administration of a structured questionnaire to university students was used to collect data for the study. A trained research assistant, who personally administered the questionnaire at different university campuses, collected the data. The data were analysed in the following ways: a descriptive analysis of the sample composition was undertaken and exploratory factor analysis was undertaken to establish the factors that contribute to mobile phone dependence. Four factors, namely mobile text usage, centrality of mobile phones, socialising and mobile phone etiquette were extracted. Dependence on mobile phones may have serious consequences for students' academic and social lives, therefore, they should strive to establish an appropriate balance between the usage of their mobile phone, their social life and their academic life.

Keywords: mobile technology; dependence; mobile phone; texting

\section{Introduction}

Technology, especially mobile technology, has dramatically invaded the lives of people in the past few years. Mobile technology, particularly mobile phones, has become part of many subcultures among the young generation in many countries (Aoki \& Downes, 2003). Coghill (2001) refers to the mobile phone as the most radiative domestic appliance ever invented. It has become ubiquitous, invading our classrooms, bedrooms and other places of social interaction. Its role has evolved in the past decade from an instrument for communication to a luxury and has recently morphed "into an appendage" (Forgays, Hyman \& Schreiber, 2014:314).

Smart-phones with their internet capabilities make frequent communication between people even easier, since these devices combine a mobile phone with the communication potential of the internet (Alderson, 2012). They have capabilities to run software that enable people to listen to music, play games and provide them with at least three possibilities to communicate with others; texting, social networking and websites. These communication techniques bring people much closer to each other (Zhang, 2012).

Constant availability could become a new norm and a different social order as interactions can happen almost anywhere. "Mobile communications may be part of the development of an online society in which everyone is expected to be available all the time and everywhere" (Arminen, 2007). Turkle (2011) remarks "from social networks to sociable robots, we're designing technologies that will give us the illusion of companionship without the demands of friendship." She concluded, as a result, "we slip into thinking that always being connected is going to make us feel less alone, but actually it's the opposite that's true" (Turkle, 2011).

Social media sites and email make it possible for people to share information with others at any time using mobile phones with internet capabilities. The mobile phone has become one of the most popular social devices. The capabilities of the mobile phone is almost endless as it is used, for example, for making and receiving calls, sending and receiving text messages, take photos and videos, read e-books, access the Internet and pay accounts (Dickson, 2010; Zhang, 2012).

Recent studies show that the new generation is more dependent on technology than those born before mobile phones were available are (Anon, 2014). Mobile phones provide great opportunities, but Hatch (2011) warns that these opportunities have come with great risks. Many studies (Ha, Chin, Park, Ryu \& Yu, 2008; Wang, Chen, \& Liang, 2011; 
Yen, Hsiao, Ko, Yen, Huang, Liu, \& Wang, 2010) find that there is a direct link between changing behaviours of individuals and technology use. These behaviours include for example health compromising behaviours and anti-social behaviours, which result in spending less time with family and friends. The overuse of mobile phones would influence people's lives negatively on both physical and mental levels (Zhang, 2012). Studies show that prolonged reading the small screens of mobile phones is harmful to the eyes and users may develop headaches, restlessness and even migraines if care is not taken.

\section{Problem Statement}

Shaw \& Fairhurst (2008) describe university students as the most 'connected' and techno-savvy generation. Lemke (1999) identify four reasons why technology is truly a benefit for students, namely technology accelerates and enriches basic skills, is incredibly motivational since it provides ease to students, facilitates new fields through simulations and three-dimensional models, and prepares students for the workforce at a young age, which is becoming more and more a vital skill. Research reports that young people use mobile phones to communicate (Livingstone \& Bober, 2005), surf the Internet (Enpocket, 2005), and organise and maintain social networks (Campbell, 2005; Williams \& Williams, 2005).

Dependence on mobile phones may impact on university students' performance. It is important, therefore, to identify and understand what factors contribute to mobile phone dependency among university students.

\section{Purpose of this Study}

The purpose of this study was to identify factors contributing to students' dependence on mobile phones.

\section{Research Methodology}

A literature review on mobile phones and its influence on people's lives were conducted. In addition, a quantitative approach was utilised, as the main purpose of the study was to objectively identify the factors contributing to mobile phone dependence. Considering that this phenomenon is under-researched in a South African context, the current study may be regarded as exploratory.

\subsection{Sample and Procedure}

A non-probability convenience sample of 350 university students from two university campuses in one of the nine provinces of South Africa formed part of this study. Students enrolled at universities constitute a particularly attractive sample because of their accessibility (Forgays et al., 2014) to collect data from regarding mobile phones. Previous studies (Auter, 2007; Economides \& Grousopoulous, 2009; Lenhart, Ling, Campbell \& Purcell, 2010) suggest that increasing numbers of students use their mobile phones for a variety of reasons. Participants were selected randomly, regardless of race or gender.

A trained research assistant, who personally administered the questionnaire at different university campuses, collected the data. Questionnaires were administered outside the lecture time of students.

\subsection{Research Instrument}

Arising from the literature review, a questionnaire, which formed part of the empirical investigation, was developed to investigate students' dependency of mobile phones. The questionnaire used to collect data was divided into two sections. Section A requested demographic information of the respondents and Section B investigated participants' dependency on mobile phones. The items in Section B were scored on a five-point Likert scale, which was graduated from one (strongly disagree) to five (strongly agree).

The questionnaire was reviewed for content validity by two academics, one being an expert in mobile technology and the other in quantitative research. The instrument was pretested with a convenient sample of 10 students to ensure that there was no confusion or ambiguity regarding the understanding of the questions and to determine how long it took to complete the questionnaire. Minor revisions were made to the questionnaire based on the feedback from the pre-test. A pilot test was conducted on a convenient sample of 60 university students to confirm the internal consistency of the scale. The Cronbach alpha reliability of the scale was 0.883 . 


\subsection{Ethical Considerations}

Participants were informed verbally by the assistant and by a covering letter of the purpose of the study. Participants were informed about their right to anonymity, confidentiality, privacy or non-participation, informed consent and protection from discomfort, harm and victimisation.

\subsection{Data Analysis}

The data for the study were captured in the Statistical Package for the Social Sciences (SPSS - version 22). Descriptive statistics were used to determine the distributional characteristics of the demographic variables and exploratory factor analysis was conducted to identify the factors contributing to dependence on mobile phones.

\section{Results}

\subsection{Demographics}

Of the 350 questionnaires which were administered, 276 completed questionnaires were returned (response rate $=78.86 \%$ ). More female respondents $(60.4 \%)$ than male respondents $(39.6 \%)$ completed the questionnaire.

The majority of the respondents (99.64\%) indicated that they own a mobile phone while 89.85 percent own a laptop. Mobile phones and laptops are preferred mobile devices, as 82.60 percent of the respondents did not own a tablet or an iPad.

\subsection{Exploratory Factor Analysis}

The appropriateness of factorability on the data set was first established. This was done by conducting the Bartlett's test of sphericity and the Kaiser-Meyer-Olkin (KMO) measure of sampling adequacy (MSA). The results of both tests (KMO = .883 ; sig. $=.000)$ provided sufficient evidence that factor analysis could be conducted on the data. Subsequently, principal component analysis (PCA) with varimax rotation was applied to the 20 items in Section B of the questionnaire. Varimax rotation, which reapportions variance among factors so that they become relatively equal in importance, was used to simplify factors by maximising the variance loadings across variables (Gillespie, Derevensky \& Gupta, 2007). An examination of the cumulative variance explained, eigenvalues equal to or greater than one and the scree plot were used to extract the factors. Four factors, which accounted for 53.25 percent of the overall variance in the scale item scores, with three to eight loadings on each factor, were extracted. These factors included mobile text usage (8 items), centrality of mobile phones ( 5 items), socialising (4 items), and mobile phone etiquette ( 3 items). Item reliability for each extracted factor was evaluated using Cronbach alpha (a). The factors' internal consistency ranged from $0.688-0.772$, which were close to or greater than the recommended significance level of 0.70 (Nunnally \& Bernstein, 1994) indicating an acceptable level of reliability. The rotated factor matrix, eigenvalues, percentage of variance explained by each factor and Cronbach alpha reliabilities provided in Table 1.

Table 1. Rotated factor loading matrix

\begin{tabular}{|c|c|c|c|c|}
\hline Item & $\begin{array}{c}\text { F1 } \\
\text { Mobile text } \\
\text { usage } \\
\end{array}$ & \begin{tabular}{|c|} 
F2 \\
Centrality of \\
mobile phones \\
\end{tabular} & \begin{tabular}{|c|} 
F3 \\
Socialising
\end{tabular} & \begin{tabular}{|c|} 
F4 \\
$\begin{array}{c}\text { Mobile phone } \\
\text { etiquette }\end{array}$ \\
\end{tabular} \\
\hline I send ten or more text messages or voice mails a day. & .773 & .081 & -.042 & -.014 \\
\hline I send text messages or voice mails when I am in class. & .670 & -.070 & .227 & .264 \\
\hline I am pleased when I receive text messages. & .604 & .299 & .092 & .156 \\
\hline $\begin{array}{l}\text { Without thinking, I check my phone for text messages or voice mails even } \\
\text { when it hasn't rung. }\end{array}$ & .580 & .165 & .219 & .144 \\
\hline I use a lot of pictographs and/or emoticons in my text messages. & .557 & .198 & .357 & -.103 \\
\hline I recharge my mobile phone's battery every day. & .453 & .391 & -.130 & .295 \\
\hline I send text messages with little content that have no practical purpose. & .447 & .063 & .479 & .100 \\
\hline I send lots of long text messages. & .424 & .313 & .097 & .046 \\
\hline My mobile phone is a bigger priority than clothes and food. & .119 & .780 & .191 & .015 \\
\hline I would rather lose my wallet or purse than my mobile phone. & .079 & .746 & .284 & .024 \\
\hline
\end{tabular}




\begin{tabular}{|c|c|c|c|c|}
\hline Item & $\begin{array}{c}\text { F1 } \\
\text { Mobile text } \\
\text { usage }\end{array}$ & \begin{tabular}{|c|} 
F2 \\
Centrality of \\
mobile phones
\end{tabular} & $\begin{array}{c}\text { F3 } \\
\text { Socialising }\end{array}$ & $\begin{array}{c}\text { F4 } \\
\text { Mobile phone } \\
\text { etiquette }\end{array}$ \\
\hline I feel unsettled when I forget to take my mobile phone with me. & .280 & .653 & .126 & .199 \\
\hline I do not really want to go to places where mobile phone signals are weak. & .090 & .543 & .225 & .491 \\
\hline I express my true feelings better by text messages than by voice mails. & .165 & .482 & .125 & .185 \\
\hline I make mobile phone calls late at night. & .006 & .129 & .733 & .294 \\
\hline I talk on my mobile phone for more than one hour a day. & .138 & .224 & .656 & .195 \\
\hline I find it hard to keep company with people who don't have mobile phones. & .157 & .355 & .535 & .176 \\
\hline I always reply to text messages and voice mails. & .329 & .238 & .468 & -148 \\
\hline $\begin{array}{l}\text { I have no problem to use my mobile phone in public places (such as } \\
\text { restaurants). }\end{array}$ & .108 & .087 & .008 & .810 \\
\hline I use my mobile phone when I am in the company of other people. & .232 & .186 & .390 & .614 \\
\hline Even when riding on a bus, I make and receive calls. & .045 & .171 & .394 & .602 \\
\hline Eigenvalues & 6.288 & 1.696 & 1.329 & 1.132 \\
\hline$\%$ of variance explained & 15.187 & 15.007 & 11.574 & 11.479 \\
\hline Cumulative \% & 15.187 & 30.195 & 41.769 & 53.248 \\
\hline Reliability (Cronbach alpha) & 0.763 & 0.772 & 0.707 & 0.688 \\
\hline
\end{tabular}

\section{Discussion}

Four factors contributing to mobile phone dependence were extracted through the percentage of variance procedure. These factors accounted for approximately 53 percent of the variance. In terms of the eigenvalue criterion, all four factors reflected an appropriate factor extraction greater than one.

Mobile text usage comprised eight items and accounted for 15.19 percent of the variance. This factor is concerned with texting, which is fast, convenient and efficient and allows for numerous discussions at once while doing other things (James, 2012). Analysis of the data revealed that participants send ten or more text messages or voice mails per day even during lecture times. It is evident that participants are pleased to receive text messages and without thinking, check their mobile phones for text messages or voice mails frequently and regularly. This finding supports those of Economides and Grousopoulou (2008) who reported that their sample of students used mobile phones mostly for conversations and texting. Pictographs and/or emoticons are used frequently in text messages. The findings of the current study corroborate those of Trifonova, Georgieva and Ronchetti (2006) who found that students used their mobile phones mainly to text pictures and messages.

Centrality of mobile phones consisted of five items and accounted for 15.01 percent of the variance. This factor refers to the critical and important position mobile phones occupy in the lives of the participants. Participants regard their mobile phones a bigger priority than clothes and food and would rather lose a wallet or purse than their mobile phones. Mobile phones are such a priority that students feel unsettled when they do not have their mobile phones with them and prefer not to go to places where mobile phone signals are weak. This finding echoes those of Kim, Chiu, Aoshim and Mitoma (2008) who argued that mobile phones have become a central and indispensible part of young people's lives. This is further emphasised by Walsh and White (2006) that individuals keep their mobile phones in close proximity despite not having any intention to use them. It is interesting to note that participants found it easier to express their feelings better by texting than by voice mails. This finding supports those of Pierce (2009) who commented that mobile phones made interaction more comfortable for those who found face-to-face communication less appealing.

Socialising consisted of four items and accounted for 11.57 percent of the variance. This factor is concerned with the socialising aspect that students experience using mobile devices. According to Hoffmeister (2012), the "new normal" is where no one is looking around anymore. In fact, no one looks up from their mobile phone's screen - everyone is immerged in their time-consuming technologies. Participants acknowledge that they make mobile phone calls late at night and talk on their mobile phones for more than one hour a day. According to Stables (1997), an important aim in technology education is to "develop positive attitudes towards their peers and understanding the value of working with others", but participants find it hard to keep company with people who do not have mobile phones.

Mobile phone etiquette consisted of three items and accounted for 11.48 percent of the variance. This factor is concerned with what is socially acceptable regarding the use of mobile phones. It refers to manners regarding the use of mobile phones. Humphreys (2005) posits that etiquette for mobile phone users has evolved at a rapid rate. While in the past students were guarded about where and how they used their mobile phones, it is not uncommon the find students unconcerned about how, where and when they use their mobile phones. Baron (2011) commented that students regularly 
multitask during lectures. They do this by texting their friends, hardly aware that they are invading the lecture space of their friends. In some instances, students' disregard for mobile phone etiquette can compromise the safety of others when, for instance, they text while crossing the road or while driving. Participants in the current study appear to have no problem using their mobile phones in public places (such as restaurants), when in the company of other people, or in confined places such as on a bus.

\section{Limitation and Implications for Further Research}

The nature of a non-probability convenience sampling method, used for this study, is a limitation of this study because data were collected in only one of the nine provinces in South Africa. Only two university campuses were involved. Therefore, generalising the results of this study to other provinces must be executed with caution.

Notwithstanding this limitation, this study makes a significant contribution to the knowledge base of students' dependence on mobile phones. Extending this study to other provinces and including more universities in the sample may provide a more comprehensive insight into dependence on mobile phones.

\section{Conclusion}

The purpose of the study was to investigate factors that contribute to mobile phone dependency. It is important to realise that as dependence on mobile phones increases, other aspects of students' are affected. This may impact negatively on their academic and social lives. Therefore, they should strive to establish an appropriate balance between their usage of their mobile phones, their social life and their academic life.

\section{References}

Alderson, J. (2012). A qualitative analysis of college student use of mobile phones for family communication. Thesis presented to the Graduate Council of Texas State, University-San Marcos, August. [Online] Available: https://digital.library.txstate.edu/bitstream/ handle/10877/4257/ALDERSON-THESIS.pdf?sequence=2. (May 13, 2013).

Anon (2014). Technology dependency and how primitive ideas can help our society survive. [Online] Available: http://jayglidden.hubpages.com/hub/Technology-Dependence-and-How-Primitive-Ideas-Can-Help-Our-Society-Survive

Aoki, K., \& Downes, E. J.(2003). An analysis of young people's use of and attitudes toward cell phones. Telematics \& Informatics, 20 , 349-364.

Arminen, I. (2007). Mobile communication society? Acta Sociologica, 50,431-437.

Auter, P. J. (2007). Portable social groups: willingness to communicate, interpersonal communication gratifications, and cell phone use among young adults. International Journal of Mobile Communications, 5(2), 139-156.

Baron, N. S. (2011). Concerns about mobile phones: a cross-national study. [Online] Available: http://firstmonday.org/ojs/index.php/fm/ article/view/3335/3032.

Campbell, M. (2005). The impact of the mobile phone on young people's social life. Paper presented to the Social Change in the 21st Century Conference Centre for Social Change Research, 28 October 2005, Queensland University of Technology, Queensland: Australia. [Online] Available: http://eprints.qut.edu.au/3492/1/3492.pdf (April 24, 2013).

Coghill, R. (2001). Inappropriate measures. The Ecologist, 31, 28-29.

Dickson, D. M. (2010). Physiological and psychological consequences of forced mobile phone abstention. Unpublished MA Thesis. San Marcos, Texas: Texas State University.

Economides, A. A., \& Grousopoulou, A. (2008). Use of mobile phones by male and female Greek students. International Journal of Mobile Communications (IJMC), 6(6), 729-749.

Enpocket (2005). Mobile media monitor survey. [Online] Available: http://www.cellular-news.com/story/13286.php (May 13, 2013).

Forgays, D. K., Hyman, I., \& Schreiber, J. (2014). Texting everywhere for everything: gender and age differences in cell phone etiquette and use. Computers in Human Behavior, 31, 314-321.

Gillespie, M., Derevensky, J., \& Gupta, R. (2007). The utility of outcome expectancies in the prediction of adolescent gambling behaviour. Journal of Gambling Issues, 19, 69-85.

Ha, J. H., Chin, B., Park, D., Ryu, S., \& Yu, J. (2008). Characteristics of excessive cellular phone use in Korean adolescents. Cyber Psychology \& Behavior, 11(6), 783-784.

Hatch, K. E. (2011). Determining the effects of technology on children. Senior honours project, paper 260. [Online]. Available: http://digitalcommunications.uri.edu/srhonorsprog/260. (April 12, 2013).

Hoffmeister, P. B. (2012). My technology is smart, but am I? [Online]. Available: http://www.huffingtonpost.com/peter-brownhoffmeister/ technology_b_1885650.html. (June 11, 2014).

Humphreys, L. (2005). Cellphones in public: social interaction in a wireless era. New Media \& Society, 7(6), 810-833.

James, M. B. (2012). Some con-text. [Online] Available: http://www.huffingtonpost.com/matthew-b-james-phd/texting- 
communication b 1940602.html (June 11, 2014).

Kim, A., Chiu, C. H., Aoshima, M., \& Mitoma, H. (2008). Influences of mobile phone text messaging on communications among the young generation in Japan, Korea and Taiwan: a comparative analysis. 1-3-10, Nishi Waseda,Shinjuku-ku,Tokyo,169-0051 JAPAN.

Lemke, C. (1999). Milken exchange on education technology in an interview with Technology Learning Magazine.

Lenhart, A., Ling, R., Campbell, S., \& Purcell, K. (2010). Teens and mobile phones. Pew Internet and American Life Project. [Online] Available: http://www.pewinternet.org (October 7, 2010)

Livingstone, S., \& Bober, M. (2005). UK children go online: final report of key project findings. London: LSE report. [Online] Available: www.children-go-online.net (May 13, 2013).

Nunnally, J. C., \& Bernstein, I. H. (1994). Psychometric theory (3rd ed.). New York: McGraw-Hill.

Pierce, T. (2009). Social anxiety and technology: face-to-face communication versus technological communication among teens. Computers in Human Behavior, 25, 1367-1372.

Shaw, S., \& Fairhurst, D. (2008). Engaging a new generation of graduates. Education and Training, 50(5), 366-378.

Stables, K. (1997). Critical issues to consider when introducing technology education into the curriculum of young learners. Journal of Technology Education. 8(2)

Trifonova, A., Georgieva, E., \& Ronchetti, M. (2006). Has the time for university's mobile learning come? Determining students' readiness. WSEAS Transactions on Advances in Engineering Education, 3(9), 1790-1979.

Turkle, S. (2011). Alone together: Why we expect more from technology and less from each other. New York: Basic Books.

Walsh, S. P., \& White, K. M. (2006). Ring, ring, why did I make that call? Beliefs underlying Australian university students' mobile phone use. Youth Studies Australia, 25(3), 49-57.

Wang, Q., Chen, W., \& Liang, Y. (2011). The effects of social media on college students. MBA student scholarship. Paper 5. Johnson \& Wales University. [Online] Available: http//scholararchieve.jwu.edu/mba_student/5 (May 04, 2014).

Williams, S., \& Williams, L. (2005). Space invaders: the negotiation of teenage boundaries through the mobile phone. The Sociological Review, 53, 314-331.

Yen, C., Hsiao, R., Ko, C., Yen, J., Huang, C., Liu, S., \& Wang, S. (2010). The relationships between body mass index and television viewing, internet use and cellular phone use: The moderating effects of socio-demographic characteristics and exercise. International Journal of Eating Disorders, 43(6), 565-571.

Zhang, G. (2012). The impact of mobile technology on people's lives. [Online] Available: http://dmsp.ace.ed.ac.uk/blog/literaryhighstreet 2012/2012/04/27/the-impact-of-mobile-technology-on-peoples-live. (April 13, 2013). 